OPEN ACCESS

Edited by:

Demosthenes Bouros,

National and Kapodistrian University

of Athens, Greece

Reviewed by:

Venerino Poletti,

Aarhus University Hospital, Denmark

Martin Petrek,

Palacký University, Olomouc, Czechia

Keren Sarah Borensztajn,

INSERM UMRS933 Physiopathologie des maladies génétiques

d'expression pédiatrique, France

*Correspondence:

Milica Vukmirovic

milica.vukmirovic@yale.edu; Naftali Kaminski

naftali.kaminski@yale.edu

Specialty section:

This article was submitted to

Pulmonary Medicine,

a section of the journal

Frontiers in Medicine

Received: 03 February 2018

Accepted: 20 March 2018

Published: 04 April 2018

Citation:

Vukmirovic M and Kaminski N (2018)

Impact of Transcriptomics on Our Understanding of Pulmonary Fibrosis.

Front. Med. 5:87.

doi: 10.3389/fmed.2018.00087

\section{Impact of Transcriptomics on Our Understanding of Pulmonary Fibrosis}

\author{
Milica Vukmirovic* and Naftali Kaminski* \\ Section of Pulmonary, Critical Care and Sleep Medicine, Precision Pulmonary Medicine Center (P²MED), Yale University \\ School of Medicine, New Haven, CT, United States
}

Idiopathic pulmonary fibrosis (IPF) is a lethal fibrotic lung disease characterized by aberrant remodeling of the lung parenchyma with extensive changes to the phenotypes of all lung resident cells. The introduction of transcriptomics, genome scale profiling of thousands of RNA transcripts, caused a significant inversion in IPF research. Instead of generating hypotheses based on animal models of disease, or biological plausibility, with limited validation in humans, investigators were able to generate hypotheses based on unbiased molecular analysis of human samples and then use animal models of disease to test their hypotheses. In this review, we describe the insights made from transcriptomic analysis of human IPF samples. We describe how transcriptomic studies led to identification of novel genes and pathways involved in the human IPF lung such as: matrix metalloproteinases, WNT pathway, epithelial genes, role of microRNAs among others, as well as conceptual insights such as the involvement of developmental pathways and deep shifts in epithelial and fibroblast phenotypes. The impact of lung and transcriptomic studies on disease classification, endotype discovery, and reproducible biomarkers is also described in detail. Despite these impressive achievements, the impact of transcriptomic studies has been limited because they analyzed bulk tissue and did not address the cellular and spatial heterogeneity of the IPF lung. We discuss new emerging technologies and applications, such as single-cell RNAseq and microenvironment analysis that may address cellular and spatial heterogeneity. We end by making the point that most current tissue collections and resources are not amenable to analysis using the novel technologies. To take advantage of the new opportunities, we need new efforts of sample collections, this time focused on access to all the microenvironments and cells in the IPF lung.

Keywords: interstitial lung diseases, idiopathic pulmonary fibrosis, transcriptomics, biomarkers, microenvironment, microarray, RNAseq

\section{INTRODUCTION}

Our understanding of idiopathic pulmonary fibrosis (IPF), a chronically progressive scarring lung disease, with a significant genetic component, has dramatically changed in the last two decades. This has happened because after years of formulating hypotheses based on animal models, or analogies from other diseases, pulmonary researchers shifted their focus to analyzing the human lung. The increased availability of well-characterized human tissues and the emergence of high throughput transcriptomic profiling technologies facilitated a new era in IPF research, one in which novel hypotheses are based on observations from human lungs. The sheer size of the data, and its unbiased nature, reintroduced serendipity in pulmonary fibrosis research, and thus led to numerous, 
previously unexpected observations, novel hypotheses and paradigm shifts. In this perspective, we provide an overview of the impact of transcriptomics on our understanding of IPF. We highlight the timeline of major discoveries (Figure 1) with a focus on mechanisms and pathways, novel biomarkers and disease classification, non-coding RNAs, and disease microenvironments.

\section{BRIEF HISTORY}

The history of transcriptomics in pulmonary fibrosis, is a story of ever increased technological throughput, enhanced sophistication of data analysis and availability of human samples. Gene expression microarrays, which allowed the parallel analysis of hundreds and later thousands of genes, emerged in the second half of the last decade of the twentieth century $(1,2)$. When the first publication of the application of microarray analysis to pulmonary fibrosis in mice was published in 2000 (3), microarrays could profile $\sim 6,000$ transcripts, the statistical approaches were not widely accepted, and human tissues were not available. Two years later, the first analysis of human lungs in 2002 included only eight samples, used a classification algorithm and did not mention a $p$-value (4). These papers were exciting and novel but very limited in numbers of samples and sophistication of analytical approaches.

Even several years later, studies that aimed at classifying disease included relatively low numbers of samples (5-10). These studies were more sophisticated in data normalization, visualization, and the wide adaptation of statistical approaches to address multiple testing $(11,12)$. Tissue availability has only increased when
NIH-NHLBI established the Lung Tissue Research Consortium, a multicenter publicly available lung tissue repository (13). The expanded availability of tissues allowed application of microarray platforms to hundreds of samples $(14,15)$ as well the public availability of data through the Lung Genomics Research Consortium (16). Development of RNAseq for deeper sequencing than with microarray platforms resulted in routine profiling of the whole transcriptome including coding and non-coding RNAs, detection of larger dynamic ranges of transcripts, and identification of novel transcripts and variants $(17,18)$. This further allowed analysis of low-input and degraded RNA samples that enabled research on lung microenvironments and archived tissues $(19,20)$. Currently, when approaching a transcriptomic study, investigators do not have to be limited by sample or technological feasibility. Instead, they can follow a rational approach to design (Figure 2). The key insights below largely follow aspects of this outline.

\section{MECHANISMS AND PATHWAYS}

Transcriptomics studies revealed numerous novel molecules and pathways highly relevant for IPF pathogenesis. Here, we describe the most prominent findings, while a more complete list is available in Table 1.

\section{Matrix Metalloproteinases}

Development of IPF was initially explained as fibroblast proliferation, higher expression of tissue inhibitor proteinases (TIMPs), and reduced activity of matrix metalloproteases (MMP) (55). The

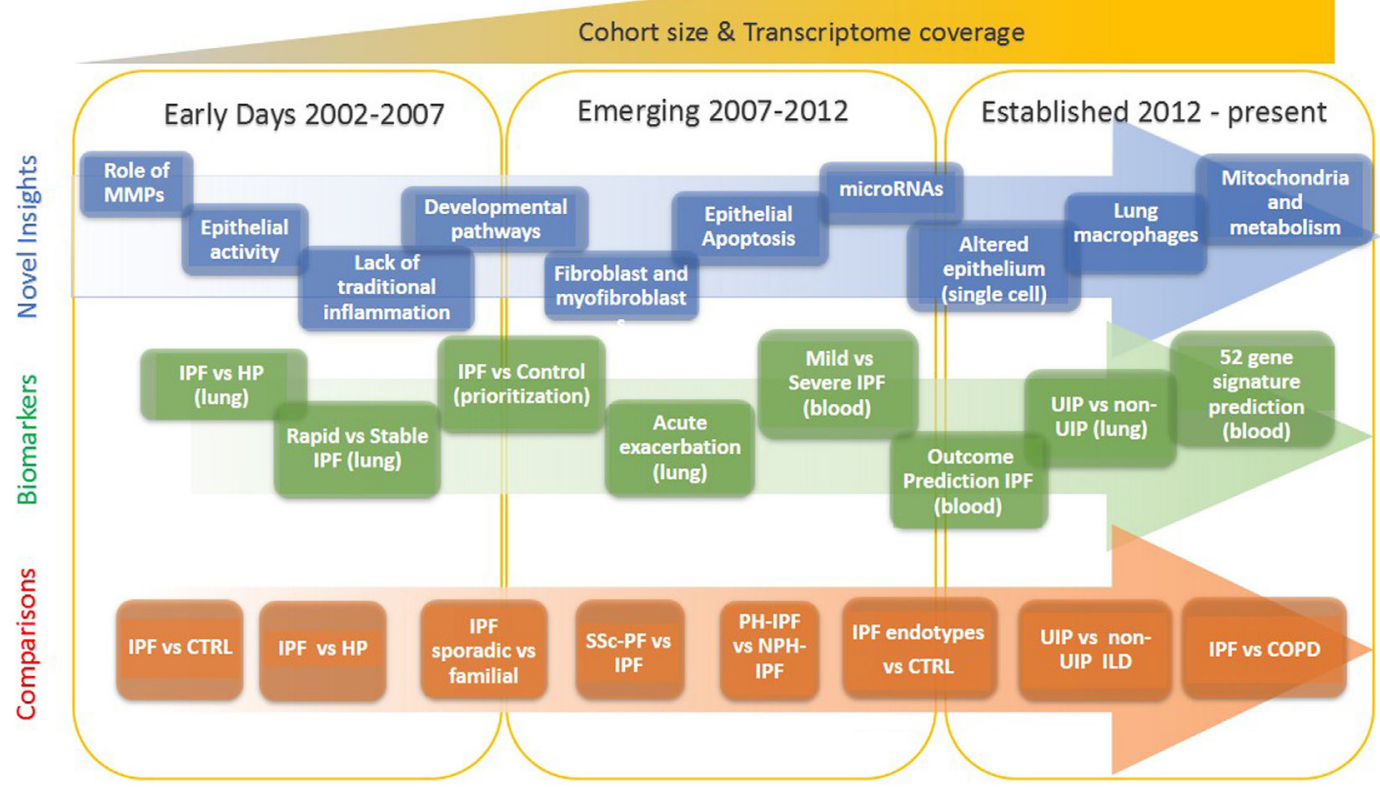

FIGURE 1 | Evolution of idiopathic pulmonary fibrosis (IPF) transcriptome analysis. The progression of IPF transcriptomic research is that of increased complexity, more genes studied, more sample studied, and more detailed phenotypes. In the early days, a few thousand genes were analyzed on a small number of samples and limited analytical approaches. During the emerging period investigators studied tens of samples, mostly on microarrays that profiled of all protein coding mRNAs. In the established period, the numbers of samples are in hundreds, all transcribed RNA is measured, and analytical methods are sophisticated. 


\section{DESIGN OF TRANSCRIPTOMICS STUDY}

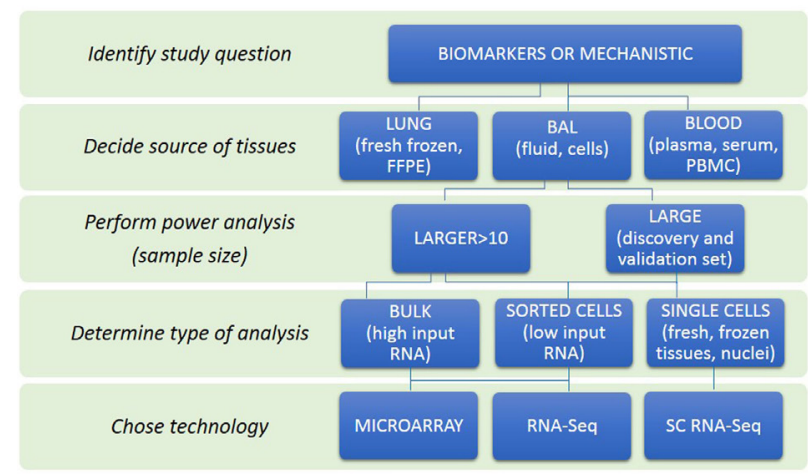

FIGURE 2 | A rational approach to design of transcriptomics study. An overview of steps to help researchers make appropriate study design is presented. First, distinguish whether study aims to identify biomarkers or mechanisms. Then, the source of tissues together with power analysis to calculate sample size to be able to answer research question should be performed. Decision about the type of analysis should be made (bulk, sorted cells, or single cells). Last, the technology to perform transcriptome analysis should be chosen.

first study that analyzed human lungs contradicted this paradigm (Figure 1; Table 1). Instead of the expected downregulation, authors found that MMPs were among the most increased genes in IPF lungs including MMP1, MMP2, MMP7, and MMP9 (4). MMP7 was localized predominantly in alveolar epithelium, and MMP7 knockout mice were relatively resistant to fibrosis (4). In addition to MMP7, MMP1 (4), MMP3 (28), MMP19 (29), and MMP28 (56) have been found to be increased in lung epithelial cells of patients with IPF, with diverse and sometimes opposing roles $(57,58)$.

While their exact roles have not been fully elucidated, the initial unexpected observation that MMPs are increased in the IPF lung, has been validated numerous times. It is now well accepted that MMPs affect numerous signaling pathways that together contribute to the profibrotic environment in the IPF lung and may also serve as effective biomarkers (see below).

\section{Genes Expressed in Lung Epithelium}

Transcriptomic analysis of bulk tissue depends on follow-up analyses to decipher the cellular origin of differentially expressed genes. One of the most surprising findings in IPF transcriptomics was that cellular origin of large number of genes that distinguish the IPF lung from controls ended up being the alveolar epithelium $(59,60)$ (Figure 1; Table 1). Among the first examples were MMP7, and later SPP1, a protein known to be expressed in inflammatory and bone cells, that in IPF is increased in the epithelial cells adjacent to myofibroblasts foci (22).

Other genes increased in IPF and unexpectedly localized to the alveolar epithelium adjacent to fibrotic regions include N-cadherin (5), HIF-1-alpha (31), IGFBP-4 (9), CCNA2 (10), TAGLN (33), CRLF1 (34), EGFR (35), and DIO2 (54). Among decreased genes, reduced expression of CAV1 (6) and AGER (52) in IPF compared with control lungs was thought to reflect changes in epithelial function or loss of type I alveolar epithelial cells (Table 1).

Of particular interest in this context, is a study that demonstrated that IPF patients with increased expression of cilia genes exhibited also increased MMP7 and MUC5B, as well as microscopic honeycombing but not myofibroblast foci on histological examination, suggesting that they represented a distinct IPF endophenotype (61) (Table 1 and see below).

\section{Fibroblasts and Fibroblast Foci Related Gene Expression}

Genes associated with myofibroblasts, a hallmark of lung histology in IPF, have been described as early as 2002 in bulk tissue analysis (4). Analysis of lung fibroblasts treated with TGFB1 revealed responses to TGFB1 and smooth muscle like myofibroblast phenotype switching (62) that was similar to what was observed in the IPF lung. Fibroblasts isolated from IPF lungs exhibited increased expression of IGFBP3 and IGFBP5 (43), TWIST1 (48), WNT5A (45), COMP (63), and FOXF1 (38). Increased Vascular cell adhesion molecule 1 gene expression in IPF lungs negatively correlated with lung function (39). Another TGFB1 induced gene, FKBP10, a collagen chaperone, was also increased in IPF and IPF lung fibroblasts and contributed to Collagen synthesis (40). Recently, TAZ, a transcriptional coactivator important in development, was shown to be increased in the fibroblastic foci and to contribute to fibrotic response through TAZ-mediated regulation of CTGF (42) (Figure 1; Table 1).

Of particular interest are genes downregulated in IPF lungs and IPF fibroblasts, as they may represent key features lost during disease. RXFP1, a relaxin/insulin-like family peptide receptor is significantly decreased in IPF tissues and fibroblasts and correlates with disease severity. A relaxin-like peptide, CGEN25009 was effective at decreasing bleomycin-induced, fibrosis in vivo (41). Similarly, PTPN11, a ubiquitously expressed SH2 domaincontaining tyrosine phosphatase, was decreased in IPF lungs and IPF fibroblasts. Overexpression of constitutively active PTPN11 reduced the responsiveness of fibroblasts to profibrotic stimuli, and viral delivery of PTPN11 to wild-type mice blunted bleomycin-induced pulmonary fibrosis (50) (Figure 1; Table 1).

\section{The WNT Pathway in IPF}

Perhaps, one of the most intriguing finding in IPF lungs gene expression was the aberrant activation of developmental pathways and especially the WNT/ $\beta$-catenin pathway in IPF (Figure 1; Table 1) $(64,65)$. In 2003, the first observation of $\beta$-catenin expression in fibroblastic foci, as well as its expression and colocalization with WNT downstream target genes, CCND1 and MMP7 in adjacent proliferative bronchiolar lesions was reported (64). Subsequently, increased WNT1, WNT7b, WNT10b, FZD2 and FZD3, $\beta$-catenin, and LEF1 were found in IPF lungs (23). WNT1, WNT3a, $\beta$-catenin, and GSK3B were mainly localized to alveolar and bronchial epithelium with increased expression of WNT targets CCND1 and MMP7. Increased expression of WISP1, a WNT inducible signaling protein, was found in IPF lungs. WISP1 had profibrotic effects in vitro, and WISP1 neutralizing antibodies blunted fibrosis in vivo (47). Inhibition of $\mathrm{WNT} / \beta$-catenin 
TABLE 1 | Summary of relevant idiopathic pulmonary fibrosis (IPF) genes identified by transcriptome profiling.

\begin{tabular}{|c|c|c|c|c|c|}
\hline Gene ID ${ }^{a}$ & Gene name & $\begin{array}{l}\text { Direction of } \\
\text { expression }\end{array}$ & Tissue localization & Relevant pathway & Reference \\
\hline \multicolumn{6}{|c|}{ Expressed in lung epithelium in IPF } \\
\hline MMP7 & Matrix metallopeptidase 7 & Increased & $\begin{array}{l}\text { Lung (alveolar epithelial cells and } \\
\text { fibroblasts), peripheral blood } \\
\text { and BAL }\end{array}$ & $\begin{array}{l}\text { Extracellular matrix degradation, } \\
\text { defensins, SPP1, and WNT/ } \beta \text { - } \\
\text { catenin pathway }\end{array}$ & $(4,5,21-27)$ \\
\hline MMP3 & Matrix metallopeptidase 3 & Increased & Lung, epithelial cells & $\begin{array}{l}\text { Extracellular matrix degradation, } \\
\beta \text {-catenin pathway }\end{array}$ & (28) \\
\hline MMP19 & Matrix metallopeptidase 19 & Increased & Lung, epithelial cells & $\begin{array}{l}\text { Extracellular matrix degradation, } \\
\text { PTGS2 pathway }\end{array}$ & (29) \\
\hline MMP1 & Matrix metallopeptidase 1 & Increased & Lung, epithelial cells & $\begin{array}{l}\text { Extracellular matrix degradation, } \\
\text { mitochondrial function/HIF-1-alpha } \\
\text { pathway }\end{array}$ & $(30)$ \\
\hline SPP1 & Osteopontin & Increased & Lung (epithelial cells) & Extracellular matrix degradation & $(9,22)$ \\
\hline IGFBP-4 & $\begin{array}{l}\text { Insulin-like growth factor binding } \\
\text { protein } 4\end{array}$ & Increased & Lung (alveolar and basal cells) & IGF1 pathway & $(5,24)$ \\
\hline CCNA2 & Cyclin A2 & Increased & Lung (alveolar epithelial cells) & Cell cycle regulation & (10) \\
\hline HIF1A & Hypoxia-inducible factor-1 alpha & Increased & Lung (alveolar epithelial cells) & Hypoxia, p53/VEGF pathways & (31) \\
\hline CAV1 & Caveolin-1 & Decreased & Lung & $\begin{array}{l}\text { Cell cycle regulation, TGF-b/JNK } \\
\text { pathway }\end{array}$ & (6) \\
\hline SYN-2 & Syndecan-2 & Increased & Lung, alveolar macrophages & TGF-b pathway & (32) \\
\hline TAGLN & Transgelin & Increased & Lung, ATIl cells & TGF-b pathway & (33) \\
\hline CRLF 1 & Cytokine receptor-like factor 1 & Increased & Lung, ATII & Th1 cells inflammatory response & (34) \\
\hline EGFR & Epidermal growth factor receptor & Increased & Lung, epithelial cells & Reepithelization & (35) \\
\hline LYCAT & Lysocardiolipin acyltransferase & Decreased & $\begin{array}{l}\text { Lung (epithelial cells), peripheral } \\
\text { blood mononuclear cell (PBMC) }\end{array}$ & Mitochondrial membrane potential & $(36)$ \\
\hline SERPINF1 (PEDF) & Pigment epithelium-derived factor & Increased & Lung & Angiogenesis & $(37)$ \\
\hline \multicolumn{6}{|c|}{ Fibroblasts related gene expression in IPF } \\
\hline FOXF1 & Forkhead box F1 & Increased & Lung & COL1/ARPC1 pathway & (38) \\
\hline VCAM-1 & Vascular cell adhesion molecule 1 & Increased & $\begin{array}{l}\text { Lung, fibroblast foci and blood } \\
\text { vessels }\end{array}$ & TGF-b/ERK/Cyclin D pathway & (39) \\
\hline FKBP10 & FK506-binding protein 10 & Increased & $\begin{array}{l}\text { Lung, fibroblasts, and CD68 (+) } \\
\text { macrophages }\end{array}$ & TGF-b/Col I synthesis & $(40)$ \\
\hline RXFP1 & $\begin{array}{l}\text { Relaxin/insulin-like family peptide } \\
\text { receptor } 1\end{array}$ & Decreased & Lung & TGF-b & $(41)$ \\
\hline $\mathrm{TAZ}$ & $\begin{array}{l}\text { Transcriptional coactivator with } \\
\text { PDZ-binding motif }\end{array}$ & Increased & Lung & CTGF and Col1 pathways & $(42)$ \\
\hline IGFBP3, IGFBP5 & $\begin{array}{l}\text { Insulin-like growth factor binding } \\
\text { proteins } 3 \text { and } 5\end{array}$ & Increased & Lung & IGF pathway & $(43)$ \\
\hline
\end{tabular}

\section{WNT pathway in IPF}

WNT1, 3a, 5a, 7b, 10b,

Fzd2 and 3, $\beta$-catenin,

Lef1, Gsk-3 $\beta$

LRP5

Wingless and others

Increased

Lung, fibroblasts, alveolar and Wnt signaling

$(23,44,45)$

Wnt co-receptor bronchial epithelium

Increased Lung, PBMC

Wnt signaling

ncreased Lung

Apoptotic response in IPF

TWIST

Twist basic helix-loop-helix transcription factor 1

CXCL12 Chemokine ligand 12

TNSF10, BAX, CASP6

Apoptotic regulators

Increased Lung-fibroblastic foci

Apoptosis/PDGF pathway

Increased Lung

Inflammation

Altered Lung

Apoptosis

SHP2 (PTPN11)

SH2 domain-containing tyrosine

expression phosphatase-2

Decreased Lung

Apoptosis/Tyr and Ser/Thr kinase pathways

Host defense implicated in IPF

DEFA3-4 AGER (RAGE)
Defensin alpha 3 and 4 Advanced glycosylation end product-specific receptor

$\begin{array}{llll}\text { Increased } & \text { Lung and peripheral blood } & \text { Host defense } & (10,51) \\ \text { Decreased } & \text { Lung and peripheral blood } & \text { Inflammation } & (24,52)\end{array}$

Mitochondria-related genes in IPF

PINK1

PTEN-induced putative kinase 1

lodothyronine deiodinase 2
Decreased Lung

Increased Lung

Dysfunction of mitochondria

TH pathway/mitochondrial 
pathway attenuated lung fibrosis in mice, suggesting an essential role of $\mathrm{WNT} / \beta$-catenin pathway in IPF development $(46,66)$.

While many of these observations were focused on epithelial cells, WNT5A, a member of the non-canonical signaling pathway was increased in IPF lung fibroblasts, with multiple observations suggesting its role in determining fibroblast phenotype in IPF $(45,67,68)$.

\section{Aging, Metabolism, and Mitochondria-Related Molecules}

Mitochondrial dysfunction is emerging as one of the key features of IPF. Gene expression data revealed decreased PINK1, a key regulator of mitophagy, and analysis of IPF lungs revealed accumulation of dysfunctional mitochondria in alveolar epithelial cells. Findings from PINK1 knockout confirmed these results, and established a role for impaired mitophagy in IPF (53) potentially through TGFB1 effects (69).

High expression of DIO2, an enzyme that activates thyroid hormone in IPF lungs, and a predisposition to fibrosis among DIO2 knockout mice, led investigators to treat bleomycin treated mice with thyroid hormone or a small molecule agonist (54). Thyroid hormone reversed bleomycin-induced mitochondrial injury both in vivo and in vitro and augmented resolution of fibrosis in mouse models of pulmonary fibrosis. This effect was dependent on intact PPARGC1A and PINK1 pathways suggesting that the antifibrotic effect of thyroid hormone was mediated through restoration of mitochondrial homeostasis (54).
Changes in expression of genes encoding numerous metabolic enzymes from IPF lungs associated with glucose, fatty acid and citric acid metabolism suggesting on large alterations in mitochondria function (70). Similar findings were found in fibroblasts and alveolar macrophages $(71,72)$. More detailed review of agerelated perturbations in genome and epigenome associating with plausible roles of mitochondria in pathogenesis were published elsewhere $(73,74)$.

\section{GENE EXPRESSION PATTERNS AS TOOLS FOR DISEASE DIAGNOSIS, CLASSIFICATION, AND OUTCOME PREDICTORS}

Transcriptomics studies have also been used to identify disease class related gene expression patterns in the lung, as well as to prioritize protein biomarkers found in the blood stream, or to identify peripheral blood mononuclear cells (PBMCs), gene expression patterns that correlate with disease clinical attributes. The studies are summarized in Table 2.

\section{Disease Classification}

An early suggestion that lung gene expression can be used to classify disease emerged from comparison of lungs of patients with IPF from those with fibrotic hypersensitivity pneumonitis (HP) using transcriptome analysis (5). The enrichment pathway analysis of the HP signature revealed T-cell activation, inflammation,

TABLE 2 | Summary of gene signatures that classify interstitial lung diseases.

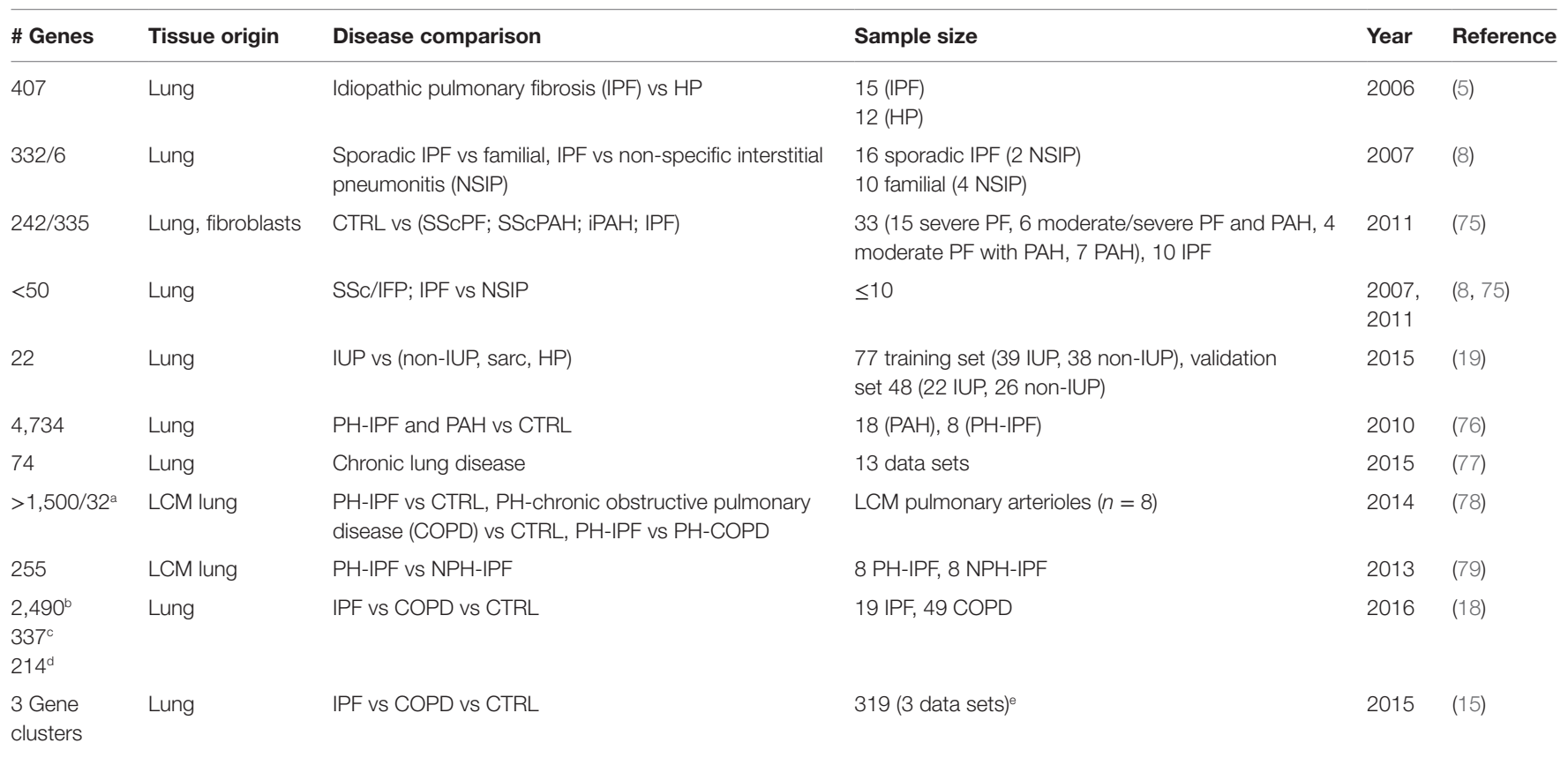

a32 small DEGs overlap between PH-IPF and PH-COPD.

b2,490 DEGs between IPF and CTRL.

'DEGs between COPD and CTRL.

${ }^{\circ}$ DEGs overlap between IPF and COPD.

e4,259 mRNA and 438 microRNA and also includes 669 clinical variables. 
and humoral immune response pathways, whereas the IPF gene signature showed enrichment for cell adhesion, extracellular matrix, and lung development pathways (80).

Analysis of lung samples obtained from patients with sporadic IPF, familial pulmonary fibrosis with a usual interstitial pneumonia (UIP) pattern, and non-specific interstitial pneumonitis (NSIP) revealed similarities on gene expression patterns and pathways and a minimal difference between IPF and NSIP (Table 2) $(5,8)$. Similar findings were found when systemic sclerosis (SSc) associated pulmonary fibrosis and IPF were compared (75).

A recent study used supervised machine learning algorithms to distinguish lung biopsy samples with UIP from non-UIP (NSIP, sarcoidosis, and HP) identified a 22 gene signature (specificity $92 \%$, sensitivity $64-82 \%$ ). This approach was solely based on transcriptional data concordant with UIP pathological findings without integration of clinical information, or comparison to patient-level diagnoses by multidisciplinary teams, the current diagnostic gold standard (19). The same group continued improving genomic classifiers to differentiate UIP from non-UIP and demonstrate high robustness toward lung tissue collection using transbronchial biopsy $(81,82)$ (Figure 1; Table 2).

\section{Lung Gene Expression Profiles Associated With Disease Activity and Severity}

Idiopathic pulmonary fibrosis has different patterns of progression, from stable disease lasting for long periods of time to rapid progression, and acute exacerbations that are highly lethal. Despite a very small number of samples, differentially expressed genes were found in end-stage lungs obtained from patients with rapid and slow progression defined by length of symptoms (Figures 1 and 2; Table 3) (7). Similar findings were also found in a study aimed to identify genes that defined progression by rate of deterioration in pulmonary function tests (9). SFTPA1, SPP1, and HSPA1A were among top increased genes and correlated with worst survival in IPF in agreement with previous reports $(83,84)$.

The study of acute exacerbations of IPF has been limited, because of lack of tissue availability. Using a unique resource of rapid lung autopsies (88) investigators compared lung gene expression profiles of acute exacerbations, stable end-stage IPF, and controls (10). They did not find any significant evidence for infection or overt inflammation in acute exacerbation lungs, but they did find increased expression of CCNA2, and DEFA3 and DEFA4, antimicrobial proteins of the alpha-defensin family known to be cleaved by MMP7 (25) and evidence for widespread epithelial apoptosis.

A more sophisticated effort to identify disease endotypes based on tissue gene expression, incorporated clinical and histological information in the analysis (61). This determined that patients with increased expression of cilia-related genes, such as DNAH6, DNAH7, DNAI1, and RPGRIP1L, exhibited also increased expression of SPP1, MMP1, MMP7, PLUNC, MUC5B, as well as more microscopic honeycombing on histology but no myofibroblastic foci (61) (Table 3). Interestingly, MMP7 has previously been shown to attenuate ciliated cell differentiation during wound repair (27). Another effort to identify disease activity genes studied gene expression commonalities between IPF disease progression in humans and bleomycin-induced lung fibrosis in rats (14). They identified the largest overlap in differentially expressed genes between lung transcriptome of bleomycin-induced fibrosis and IPF human lungs and identified 12 genes (C6, CTHRC1, CTSE, FHL2, GAL, GREM1, LCN2, MMP7, NELL1, PCSK1, PLA2G2A, and SLC2A5) as translational markers of disease activity. Of those markers, four classified IPF patients based on disease severity (14).

\section{Cross Disease Endotypes}

The availability of large datasets such as the LGRC, allowed also analysis of multiple chronic lung disease in parallel. Recently, applying a novel computational approach named integrative phenotyping framework, investigators discovered novel endotypes of chronic obstructive pulmonary disease (COPD) and IPF (15). They integrated clinical phenotype data with mRNA and microRNA data and identified novel patient clusters. The genes that characterized the patients in the intermediate clusters were enriched with inflammatory and immune pathways, suggesting that patients from those clusters could have a mechanistically distinct autoimmune endotypes (15). Similarly, the same group integrated mRNA, microRNA, and splicing gene variants to identify convergent transcriptional regulatory networks in IPF and COPD (18). The p53/hypoxia pathway emerged as a convergent pathway in COPD and IPF. A recent study performed meta-analysis of 13 published data

TABLE 3 | Summary of gene signatures that predict idiopathic pulmonary fibrosis (IPF) progression [rapid vs slow (stable)].

\begin{tabular}{|c|c|c|c|c|}
\hline \# Genes & Tissue origin & Sample size (IPF) & Year & Reference \\
\hline 437 & Lung & 26 (rapid progressors), 88 (slow progressors) & 2007 & $(7)$ \\
\hline 579 & Lung & 23 (stable), 8 (acute exacerbation) & 2009 & (10) \\
\hline 134 & Lung & 6 (stable), 6 (progressive) & 2009 & (9) \\
\hline 472 & Lung & 119 (training), 111 (validation) & 2013 & (61) \\
\hline $468 / 12^{b}$ & Bleomycin rat/IPF human & 100 (human), 73 (rats) & 2015 & (14) \\
\hline $1,428 / 2,790 / 13^{a}$ & Peripheral blood mononuclear cell (PBMC) & 130 (mild vs ctrl; severe vs ctrl; mild vs severe) & 2012 & (51) \\
\hline 118 & PBMC & 45 (training), 21 and 75 (validation) & 2015 & (85) \\
\hline 52 & PBMC & 45 (discovery), 75 (validation), and 425 (validation) & 2013,2017 & $(86,87)$ \\
\hline
\end{tabular}

a13 DEGs between mild and severe IPF.

${ }^{b} 12$ is set of translational markers. 
sets including cystic fibrosis, COPD, IPF and asthma, environmental conditions (smoking, epithelial injury), and control to identify general markers of chronic lung disease (77). Increased inflammatory, wounding, defense response and regulation of cell proliferation pathways, and decreased immune response pathways were observed (77). While intriguing, all of these studies were limited by lack of resolution with regard to cellular admixture and depth of clinical phenotyping (Figure 1; Table 2).

\section{Prioritization of Protein Biomarkers}

Genome scale transcriptome studies facilitated the development of protein-based biomarkers for IPF diagnosis (Figures 1 and 2; Table 4). A comparison of proteins in the blood flow of patients with IPF to control using a targeted proteomic approach identified a signature of MMP1, MMP7, MMP8, IGFBP1, and TNFRSA1F (24) that was able to distinguish IPF from controls with high sensitivity and specificity. MMP 1 and MMP 7 were also increased in the lungs of IPF patients and able to differentiate IPF patients from other chronic lung disease including hypersensitivity pneumonitis and sarcoidosis.

Indeed, MMP7, which emerged out of the first microarray analysis of human IPF lungs, was replicated as predictive of increased mortality in multiple cohorts of IPF patients $(14,26$, 90-92, 95). Similar experimental strategy, following a lung gene expression finding with assessment of a protein in the peripheral blood, has been applied to many molecules including SPP1 (22), COMP (63), CXCL13 (93), CCL8 (94), and others (Table 4).

\section{Peripheral Blood Gene Expression Patterns}

The transcriptome of the peripheral blood is highly appealing because of information about disease presence and outcome. It represents a safe and accessible alternative to availability of samples from the lung. Microarray gene expression profiles of whole blood RNA (51) distinguished IPF patients from controls, and among IPF patients, 13 genes were changed with increased disease severity as assessed by DLCO but not FVC (Figures $\mathbf{1}$ and 2; Table 3) (51). Interestingly, alpha-defensins identified in acute exacerbations in the lung (10) were also associated with disease severity in the peripheral blood.

A subsequent study aimed to identify PBMC gene expression profiles predictive of increased mortality in patients with IPF (86). The authors performed microarray analysis on RNA isolated from PBMCs in discovery and replication cohorts of IPF patients. They identified a 52-gene outcome-predictive signature that distinguished two patient groups with significant differences in transplant free survival in both cohorts. Interestingly, increased mortality was associated with decreases in the T-cell co-stimulatory molecules CD28, ICOS, LCK, and ITK, potentially highlighting the role of potential T-cell aberrations and maybe the role of immunosenescence in IPF. Remarkably, the outcome-predictive accuracy of a score calculated based on the 52-gene signature was recently validated in a six cohorts study containing 425 IPF patients (87). Adding the 52-gene risk score to the Gender, Age, and Physiology index significantly improved its mortality predictive accuracy, suggesting that the genomic signature improved on the performance of validated clinical markers. Analysis of longitudinal changes in the signature revealed that while the 52-gene risk score tracked changes in FVC, patients never shifted their risk profile. However, in a subset of treated patients, a shift in the risk score was also accompanied by functional improvement, suggesting that the 52-gene signature may be indicative of response to the therapy. These datasets were also used in manuscripts that applied Weighted Gene Co-expression Network Analysis to identify gene expression modules that correlate with outcome (85) or microbiome changes (96) (Table 3). The impressive accuracy and replication should drive experiments that test the value of these biomarkers prospectively and assess in detail shift in circulating inflammatory cells in IPF using unbiased methods such as single-cell RNAseq.

\section{ROLE OF NON-CODING RNAs IN IPF}

Until recently considered the dark matter of the genome, the significant role of non-coding RNAs in human health and disease is increasingly appreciated (97). We will focus here on microRNAs, as their role has been extensively studied in pulmonary fibrosis.

\section{MicroRNA Changes Reveal Loss of Differentiation}

MicroRNAs are small non-coding RNAs that regulate gene expression by either initiating RNA degradation or inhibiting translation through binding to the 3' UTR of their target gene. Acting as rheostats, many microRNAs regulate the general responsiveness of a cell to a certain stimulus by affecting numerous genes and frequently serving as gate keepers of feed forward

TABLE 4 | Summary of single genes - biomarkers of idiopathic pulmonary fibrosis (IPF) progression.

\begin{tabular}{|c|c|c|c|c|c|}
\hline Gene ID & Gene name & Tissue origin & Sample size (IPF) & Year & Reference \\
\hline MMP7 & Matrix metallopeptidase 7 & Lung, serum, plasma, BAL & $\begin{array}{l}13 \text { (lung), } 74 \text { (plasma, lung, BAL) } \\
20 \text { (BAL) } \\
214 \text { (plasma, } 140 \text { derivation and } 101 \text { validation) } \\
65 \text { (serum), 1,227 (serum), } 97 \text { (plasma) }\end{array}$ & $\begin{array}{l}2002,2008 \\
2009 \\
2012 \\
2016,2017\end{array}$ & $\begin{array}{l}(4,24) \\
(89) \\
(26) \\
(90,91,92)\end{array}$ \\
\hline SPP1 & Osteopontin & Lung, BAL & 18 & 2005 & (22) \\
\hline COMP & Cartilage oligomeric matrix protein & Lung & 115 & 2013 & (63) \\
\hline CXCL13 & C-X-C motif chemokine 13 & Lung, plasma & 92,94 & 2014 & (93) \\
\hline CCL8 & Chemokine (C-C motif) ligand 8 & Lung, BAL, plasma & 8 (lung), 86 (BAL, plasma) & 2017 & (94) \\
\hline
\end{tabular}


loops. The expression of approximately $10 \%$ of the microRNAs is different in IPF compared with control lungs $(98,99)$. The microRNA expression patterns observed in IPF are similar to those observed in the developing lung. Comparison of fetal, IPF and control lungs revealed that miR-487b, miR-409-3p, miR-154, miR-154*, miR-134, miR-299-5p, miR-410, miR-382, miR-377, and miR-296 were increased in IPF or fetal lungs compared with controls (99). A time course systems biology analysis of microRNAs changed during postnatal lung development suggested that close to $40 \%$ were also changed in IPF (100). In the same vein, comparison of microRNA signatures in IPF and non-small cell lung cancer revealed significant similarities and numerous microRNAs that changed in the same direction. Notably, over 20 microRNAs including members of the miR-30, let-7, miR-29 families were decreased in IPF and lung cancer, commonly increased microRNAs included miR-155, miR-21, miR-205, and miR-31 (101). While the cellular origin and exact effects of all of these common microRNA changes are unclear, together with the observations about lung development, microRNA changes in the IPF lung suggest a loss of the differentiated organ regulatory networks potentially as a result of desynchronized aging $(102,103)$.

\section{IPF MicroRNAs and TGFB1}

One of the most recurrent themes in microRNAs in IPF, is that they are both regulated by and regulators of TGFB1 signaling. Thus, in many cases, a change in the expression of a microRNA disrupts the careful balance of self-limited activation of TGFB1. Let-7d, a microRNA known to regulate epithelial cell differentiation, is a good example. It is decreased in IPF lungs, it is inhibited by TGFB1 through direct effect of SMAD3, and when it is inhibited, it ceases to inhibit HMGA2, allowing amplification of TGFB1 signaling and early fibrotic changes in vivo and in vitro (98). Similarly, miR-21, a microRNA increased in IPF lungs, is induced by TGFB1 and is an inhibitor of SMAD7, a regulatory SMA that inhibits TGFB1 signaling pathways (104). A larger number of TGFB1 inducible microRNAs, localized to chromosome 14q32, were also increased in IPF lungs (99). Other microRNAs regulating or regulated by TGFB1 were found to be changed in IPF lungs include miR-30, miR-199, miR-29, miR-26, miR-155, miR-326, and others (105). While, it can be safely said that microRNA changes in IPF seem to result in lowering the cell profibrotic threshold, it has to be mentioned that they were obtained in isolation, for one microRNA at a time, but in the IPF lung, at least when analyzed in bulk, they happen simultaneously. To understand better the effects of microRNA perturbations, careful dissection of the cellular, spatial, and temporal changes, as well as their integrated effects is required.

\section{miR-29, the Ultimate Antifibromir}

Of microRNAs differentially expressed in IPF, the miR-29 family is probably the most extensively studied both mechanistically and as a therapeutic target, because of its known inhibitory effects on extracellular matrix proteins, and growth factors such CTGF and IGF1 (106). miR-29 family members are decreased in cardiac,
TABLE 5 | Data and tissue repositories.

\begin{tabular}{llc}
\hline Name & Website & Reference \\
\hline $\begin{array}{l}\text { Lung Tissue Research } \\
\text { Consortium }\end{array}$ & http://www.ltrcpublic.com/ & (126) \\
Lung Genomics Research & http://www.lung-genomics.org/ & $(126)$ \\
Consortium & https://www.lungmap.net/ & $(127,128)$ \\
Lung development map & http://www.cs.cmu.edu/ jund/ & $(129)$ \\
Cell differentiation analysis & scdiff/index.html \\
(scRNAseq) &
\end{tabular}

renal and liver fibrosis, keloid, fibrotic Crohn's disease, and other fibrotic conditions (107-113). miR-29 family microRNAs are decreased in IPF lungs (114), they regulate numerous genes related to fibrosis (115) and seem to regulate profibrotic signals from the extracellular matrix to fibroblasts (116). Both gene delivery of miR-29 via a transposon method (117) or using a miR29b mimic (118) augmented resolution of bleomycin-induced pulmonary fibrosis. While most of these studies focused on the role of miR-29 in fibroblasts, two recent studies suggested that miR-29 could be important in prevention of pulmonary fibrosis (119) or bronchopulmonary dysplasia (120) through beneficial effects on alveolar repair. Regardless of the cell specificity of the effect, miR-29 supplementation seems a viable option as an antifibrotic therapy.

\section{IPF MICROENVIRONMENTS}

The IPF lung is characterized histologically by its regional, temporal and cellular heterogeneity, meaning that normal looking regions are interspersed with diseased regions, different regions may appear at different stages of disease $(121,122)$, and both the cellular content and the phenotype of known cells are dramatically altered in the IPF lung. Transcriptomic profiles of bulk tissue homogenates do not capture this complexity. They also do not allow understanding how cells influence each other in the remodeled IPF microenvironment. Improving the cellular and spatial resolution of transcriptomics using single cells and tissue microenvironments is critically important to decipher what happens in the IPF lung.

\section{Tissue and Cellular Heterogeneity Are Starting to Emerge}

Transcriptome analyses performed on bulk lung tissue detected strong gene expression signals, leading to discovery of IPF relevant signaling pathways (Figures 1 and 2). However, it is unclear whether alteration in transcriptome signals represented core features of disease or was dominated by changes in cellular admixture. Increased gene expression changes observed in the IPF lung were frequently assigned to cell types, based on prior knowledge or follow-up studies, as in the case of MMP7, SPP1, WISP1, COMP, TWIST1, PINK1, and the others mentioned earlier. In most cases, such analysis was done after the fact, using low throughput technologies such as immunohistochemistry, and was dependent on prior knowledge and availability of reagents. Only few studies analyzed transcriptomic gene expression 


\section{Triangulation of Transcriptomic Data to Better Understand Disease}



FIGURE 3 | Triangulation of transcriptomic data to understand disease. Single cell, microenvironment, and bulk tissue transcriptomic analysis have their advantages and disadvantages. When applied together, they can help in understanding regulatory networks in the tissue.

in well-defined IPF microenvironments. Comparison of the transcriptome of hyperplastic vs conserved epithelial cells and dense fibrotic lung regions, using laser capture microdissections identified previously unrecognized MMP19, as a molecule increased in hyperplastic epithelial cells, with an antifibrotic role (29). Two studies reported solely gene expression profiles of pulmonary vasculature and showed differential gene expression for IPF patients with and without coexistent PH (79) and for PH-IPF and COPD (78) (Table 2). Two clusters of co-regulated genes related to bronchiolar epithelium or lymphoid aggregates were identified when whole lung transcriptome was correlated with tissues histology and clinical variables (123). The first study to apply single-cell RNAseq of sorted epithelial cells from IPF patients or controls revealed distinct epithelial cell types in IPF lung and complete lack of some "normal" epithelial cells (124). Using transcriptomic profiling of flow-sorted cells, monocytes shown to differentiate into alveolar macrophages and continuously express profibrotic genes over the course of fibrosis. Thus, selective targeting of alveolar macrophage differentiation within the lung may decrease fibrosis and avoid global monocyte or tissue-resident alveolar macrophage depletion (125). Besides transcriptomics profiling of sorted and single cells isolated from fresh lung, the RNAseq of archival formalin-fixed paraffinembedded lung biopsy from IPF patients is possible (20). This allows analysis of specific areas of lungs and their interaction observed microscopically (epithelium and fibroblastic foci), usage of clinical variables (survival) and overcoming the availability of fresh lung tissues.

While lung microenvironment studies are still rare, the rapid emergence of methods for high throughput sequencing of single cells, the improved ability to perform sequencing from IPF microenvironments, the improved analytical methods, and the success of old fashioned analyses of bulk tissue should encourage investigators to perform larger studies focusing on understanding temporo-spatial multicellular networks in IPF.

\section{CONCLUSION AND FUTURE DIRECTIONS}

The progress of transcriptomics in IPF is characterized by increased sophistication and complexity (Figure 1). Transcriptomics studies facilitated multiple shifts with regard to the role of MMPs, developmental pathways, microRNAs, and the importance of alveolar epithelial and myofibroblast regulatory networks in IPF. They have also had significant impact on the discovery and prioritization of validated biomarkers (Figure 1). However, most of these studies used low sample number and lack validation cohorts. NIH NHLBI funded efforts led to generation of publicly available datasets of multi-omics data generated from carefully characterized human and mouse samples (Table 5). They contain, mainly bulk tissue, but also limited amounts of sorted cells and single-cell transcriptomic profiles. With the advent of novel technologies for single cell and microenvironment transcriptomic profiling, we have a unique opportunity to triangulate IPF regulatory and transcriptional networks by analyzing the lung from a verity of perspectives, use available bulk data, as well as profiles of disease microenvironments and single cells (Figure 3). This will allow integration of information and resolution of the cellular, temporal, and spatial complexities of the IPF lungs and thus better therapeutics and diagnostics. In 2014 following a series of meetings sponsored by NIH-NHLBI, 
the Pulmonary Fibrosis Foundation and the American Thoracic Society Assembly of Respiratory, Cell and Molecular Biology convened a series of meetings that recommended among other things, an open access biorepository for IPF research (126). While various registries have been formed, new centralized efforts to obtain IPF lung tissues have not been renewed. This is a problem, because most current tissue collections are not amenable to analysis using the novel technologies. To take advantage of the new opportunities, to continue the momentum of transcriptomic success we need new efforts of sample collections, this time focused on access to all the microenvironments and cells in the IPF lung.

\section{REFERENCES}

1. Pease AC, Solas D, Sullivan EJ, Cronin MT, Holmes CP, Fodor SP. Lightgenerated oligonucleotide arrays for rapid DNA sequence analysis. Proc Natl Acad Sci U S A (1994) 91:5022-6. doi:10.1073/pnas.91.11.5022

2. Schena M, Shalon D, Davis RW, Brown PO. Quantitative monitoring of gene expression patterns with a complementary DNA microarray. Science (1995) 270:467-70. doi:10.1126/science.270.5235.467

3. Kaminski N, Allard JD, Pittet JF, Zuo F, Griffiths MJ, Morris D, et al. Global analysis of gene expression in pulmonary fibrosis reveals distinct programs regulating lung inflammation and fibrosis. Proc Natl Acad Sci U S A (2000) 97:1778-83. doi:10.1073/pnas.97.4.1778

4. Zuo F, Kaminski N, Eugui E, Allard J, Yakhini Z, Ben-Dor A, et al. Gene expression analysis reveals matrilysin as a key regulator of pulmonary fibrosis in mice and humans. Proc Natl Acad Sci U S A (2002) 99:6292-7. doi:10.1073/ pnas.092134099

5. Selman M, Pardo A, Barrera L, Estrada A, Watson SR, Wilson K, et al. Gene expression profiles distinguish idiopathic pulmonary fibrosis from hypersensitivity pneumonitis. Am J Respir Crit Care Med (2006) 173:188-98. doi:10.1164/rccm.200504-644OC

6. Wang XM, Zhang Y, Kim HP, Zhou Z, Feghali-Bostwick CA, Liu F, et al. Caveolin-1: a critical regulator of lung fibrosis in idiopathic pulmonary fibrosis. J Exp Med (2006) 203:2895-906. doi:10.1084/jem.20061536

7. Selman M, Carrillo G, Estrada A, Mejia M, Becerril C, Cisneros J, et al. Accelerated variant of idiopathic pulmonary fibrosis: clinical behavior and gene expression pattern. PLoS One (2007) 2:e482. doi:10.1371/journal.pone.0000482

8. Yang IV, Burch LH, Steele MP, Savov JD, Hollingsworth JW, McelvaniaTekippe E, et al. Gene expression profiling of familial and sporadic interstitial pneumonia. Am J Respir Crit Care Med (2007) 175:45-54. doi:10.1164/ rccm.200601-062OC

9. Boon K, Bailey NW, Yang J, Steel MP, Groshong S, Kervitsky D, et al. Molecular phenotypes distinguish patients with relatively stable from progressive idiopathic pulmonary fibrosis (IPF). PLoS One (2009) 4:e5134. doi:10.1371/ journal.pone.0005134

10. Konishi K, Gibson KF, Lindell KO, Richards TJ, Zhang Y, Dhir R, et al. Gene expression profiles of acute exacerbations of idiopathic pulmonary fibrosis. Am J Respir Crit Care Med (2009) 180:167-75. doi:10.1164/rccm.200810-1596OC

11. Dave NB, Kaminski N. Analysis of microarray experiments for pulmonary fibrosis. Methods Mol Med (2005) 117:333-58. doi:10.1385/1-59259-940-0:333

12. Segal E, Friedman N, Kaminski N, Regev A, Koller D. From signatures to models: understanding cancer using microarrays. Nat Genet (2005) 37(Suppl):S38-45. doi:10.1038/ng1561

13. NIH-NHLBI. Lung Tissue Resource Consortium. (2005). Available from: https://ltrcpublic.com (Accessed: March 15, 2018).

14. Bauer Y, Tedrow J, De Bernard S, Birker-Robaczewska M, Gibson KF, Guardela BJ, et al. A novel genomic signature with translational significance for human idiopathic pulmonary fibrosis. Am J Respir Cell Mol Biol (2015) 52:217-31. doi:10.1165/rcmb.2013-0310OC

15. Kim S, Herazo-Maya JD, Kang DD, Juan-Guardela BM, Tedrow J, Martinez FJ, et al. Integrative phenotyping framework (iPF): integrative clustering of multiple omics data identifies novel lung disease subphenotypes. BMC Genomics (2015) 16:924. doi:10.1186/s12864-015-2170-4

\section{AUTHOR CONTRIBUTIONS}

MV and NK substantially contributed to review design; data analysis and interpretation. Both the authors participated in writing and revising the review, approved the final work, and agreed to be accountable for all aspects of the review.

\section{FUNDING}

The work was in part supported by US National Institute of Health (NIH) grants R01HL095397, R01HL127349, U01 HL122626, UH2 HL123886, and U54HG008540 (NK).

16. Quackenbush J, Kaminski N, Schwartz DA, Spira A. Lung Genomics Research Consoritum Download Page [Online]. (2013). Available from: http://www. lung-genomics.org (Accessed: March 15, 2018).

17. Yang IV, Pedersen BS, Rabinovich E, Hennessy CE, Davidson EJ, Murphy E, et al. Relationship of DNA methylation and gene expression in idiopathic pulmonary fibrosis. Am J Respir Crit Care Med (2014) 190:1263-72. doi:10.1164/ rccm.201408-1452OC

18. Kusko RL, Brothers JF II, Tedrow J, Pandit K, Huleihel L, Perdomo C, et al. Integrated genomics reveals convergent transcriptomic networks underlying chronic obstructive pulmonary disease and idiopathic pulmonary fibrosis. Am J Respir Crit Care Med (2016) 194:948-60. doi:10.1164/rccm.201510-2026OC

19. Kim SY, Diggans J, Pankratz D, Huang J, Pagan M, Sindy N, et al. Classification of usual interstitial pneumonia in patients with interstitial lung disease: assessment of a machine learning approach using high-dimensional transcriptional data.Lancet Respir Med (2015) 3:473-82. doi:10.1016/S2213-2600(15)00140-X

20. Vukmirovic M, Herazo-Maya JD, Blackmon J, Skodric-Trifunovic V, Jovanovic D, Pavlovic S, et al. Identification and validation of differentially expressed transcripts by RNA-sequencing of formalin-fixed, paraffin-embedded (FFPE) lung tissue from patients with idiopathic pulmonary fibrosis. BMC Pulm Med (2017) 17:15. doi:10.1186/s12890-016-0356-4

21. Cosgrove GP, Schwarz MI, Geraci MW, Brown KK, Worthen GS. Overexpression of matrix metalloproteinase-7 in pulmonary fibrosis. Chest (2002) 121:25s-6s. doi:10.1378/chest.121.3_suppl.25S-a

22. Pardo A, Gibson K, Cisneros J, Richards TJ, Yang Y, Becerril C, et al. Up-regulation and profibrotic role of osteopontin in human idiopathic pulmonary fibrosis. PLoS Med (2005) 2:e251. doi:10.1371/journal.pmed.0020251

23. Konigshoff M, Balsara N, Pfaff EM, Kramer M, Chrobak I, Seeger W, et al. Functional Wnt signaling is increased in idiopathic pulmonary fibrosis. PLoS One (2008) 3:e2142. doi:10.1371/journal.pone.0002142

24. Rosas IO, Richards TJ, Konishi K, Zhang Y, Gibson K, Lokshin AE, et al. MMP1 and MMP7 as potential peripheral blood biomarkers in idiopathic pulmonary fibrosis. PLoS Med (2008) 5:e93. doi:10.1371/journal.pmed.0050093

25. Wilson CL, Schmidt AP, Pirila E, Valore EV, Ferri N, Sorsa T, et al. Differential processing of $\{$ alpha $\}$ - and $\{$ beta $\}$-defensin precursors by matrix metalloproteinase-7 (MMP-7). J Biol Chem (2009) 284:8301-11. doi:10.1074/jbc. M809744200

26. Richards TJ, Kaminski N, Baribaud F, Flavin S, Brodmerkel C, Horowitz D, et al. Peripheral blood proteins predict mortality in idiopathic pulmonary fibrosis. Am J Respir Crit Care Med (2012) 185:67-76. doi:10.1164/rccm. 201101-0058OC

27. Gharib SA, Altemeier WA, Van Winkle LS, Plopper CG, Schlesinger SY, Buell CA, et al. Matrix metalloproteinase-7 coordinates airway epithelial injury response and differentiation of ciliated cells. Am J Respir Cell Mol Biol (2013) 48:390-6. doi:10.1165/rcmb.2012-0083OC

28. Yamashita CM, Dolgonos L, Zemans RL, Young SK, Robertson J, Briones N, et al. Matrix metalloproteinase 3 is a mediator of pulmonary fibrosis. Am J Pathol (2011) 179:1733-45. doi:10.1016/j.ajpath.2011.06.041

29. Yu G, Kovkarova-Naumovski E, Jara P, Parwani A, Kass D, Ruiz V, et al. Matrix metalloproteinase-19 is a key regulator of lung fibrosis in mice and humans. Am J Respir Crit Care Med (2012) 186:752-62. doi:10.1164/rccm.201202-0302OC

30. Herrera I, Cisneros J, Maldonado M, Ramirez R, Ortiz-Quintero B, Anso E et al. Matrix metalloproteinase (MMP)-1 induces lung alveolar epithelial cell 
migration and proliferation, protects from apoptosis, and represses mitochondrial oxygen consumption. J Biol Chem (2013) 288:25964-75. doi:10.1074/jbc. M113.459784

31. Tzouvelekis A, Harokopos V, Paparountas T, Oikonomou N, Chatziioannou A, Vilaras G, et al. Comparative expression profiling in pulmonary fibrosis suggests a role of hypoxia-inducible factor-1alpha in disease pathogenesis. Am J Respir Crit Care Med (2007) 176:1108-19. doi:10.1164/rccm.200705-683OC

32. Shi Y, Gochuico BR, Yu G, Tang X, Osorio JC, Fernandez IE, et al. Syndecan-2 exerts antifibrotic effects by promoting caveolin-1-mediated transforming growth factor-beta receptor I internalization and inhibiting transforming growth factor-beta1 signaling. Am J Respir Crit Care Med (2013) 188:831-41. doi:10.1164/rccm.201303-0434OC

33. Yu H, Konigshoff M, Jayachandran A, Handley D, Seeger W, Kaminski N, et al. Transgelin is a direct target of TGF-beta/Smad3-dependent epithelial cell migration in lung fibrosis. FASEB J (2008) 22:1778-89. doi:10.1096/ f. $.07-083857$

34. Kass DJ, Yu G, Loh KS, Savir A, Borczuk A, Kahloon R, et al. Cytokine-like factor 1 gene expression is enriched in idiopathic pulmonary fibrosis and drives the accumulation of $\mathrm{CD} 4+\mathrm{T}$ cells in murine lungs: evidence for an antifibrotic role in bleomycin injury. Am J Pathol (2012) 180:1963-78. doi:10.1016/j.ajpath.2012.01.010

35. Tzouvelekis A, Ntolios P, Karameris A, Vilaras G, Boglou P, Koulelidis A, et al. Increased expression of epidermal growth factor receptor (EGF-R) in patients with different forms of lung fibrosis. Biomed Res Int (2013) 2013:654354. doi:10.1155/2013/654354

36. Huang LS, Mathew B, Li H, Zhao Y, Ma SF, Noth I, et al. The mitochondrial cardiolipin remodeling enzyme lysocardiolipin acyltransferase is a novel target in pulmonary fibrosis. Am J Respir Crit Care Med (2014) 189:1402-15. doi:10.1164/rccm.201310-1917OC

37. Cosgrove GP, Brown KK, Schiemann WP, Serls AE, Parr JE, Geraci MW, et al. Pigment epithelium-derived factor in idiopathic pulmonary fibrosis: a role in aberrant angiogenesis. Am J Respir Crit Care Med (2004) 170:242-51. doi:10.1164/rccm.200308-1151OC

38. Melboucy-Belkhir S, Pradere P, Tadbiri S, Habib S, Bacrot A, Brayer S, et al. Forkhead Box F1 represses cell growth and inhibits COL1 and ARPC2 expression in lung fibroblasts in vitro. Am J Physiol Lung Cell Mol Physiol (2014) 307:L838-47. doi:10.1152/ajplung.00012.2014

39. Agassandian M, Tedrow JR, Sembrat J, Kass DJ, Zhang Y, Goncharova EA, et al. VCAM-1 is a TGF-betal inducible gene upregulated in idiopathic pulmonary fibrosis. Cell Signal (2015) 27:2467-73. doi:10.1016/j.cellsig.2015.09.003

40. Staab-Weijnitz CA, Fernandez IE, Knuppel L, Maul J, Heinzelmann K, Juan-Guardela BM, et al. FK506-binding protein 10, a potential novel drug target for idiopathic pulmonary fibrosis. Am J Respir Crit Care Med (2015) 192:455-67. doi:10.1164/rccm.201412-2233OC

41. Tan J, Tedrow JR, Dutta JA, Juan-Guardela B, Nouraie M, Chu Y, et al. Expression of RXFP1 is decreased in idiopathic pulmonary fibrosis. implications for relaxin-based therapies. Am J Respir Crit Care Med (2016) 194:1392-402. doi:10.1164/rccm.201509-1865OC

42. Noguchi S, Saito A, Mikami Y, Urushiyama H, Horie M, Matsuzaki H, et al. TAZ contributes to pulmonary fibrosis by activating profibrotic functions of lung fibroblasts. Sci Rep (2017) 7:42595. doi:10.1038/srep42595

43. Pilewski JM, Liu L, Henry AC, Knauer AV, Feghali-Bostwick CA. Insulin-like growth factor binding proteins 3 and 5 are overexpressed in idiopathic pulmonary fibrosis and contribute to extracellular matrix deposition. Am J Pathol (2005) 166:399-407. doi:10.1016/S0002-9440(10)62263-8

44. Studer SM, Kaminski N. Towards systems biology of human pulmonary fibrosis. Proc Am Thorac Soc (2007) 4:85-91. doi:10.1513/pats.200607-139JG

45. Vuga LJ, Ben-Yehudah A, Kovkarova-Naumovski E, Oriss T, Gibson KF, Feghali-Bostwick C, et al. WNT5A is a regulator of fibroblast proliferation and resistance to apoptosis. Am J Respir Cell Mol Biol (2009) 41:583-9. doi:10.1165/rcmb.2008-02010C

46. Lam AP, Herazo-Maya JD, Sennello JA, Flozak AS, Russell S, Mutlu GM, et al. Wnt coreceptor Lrp5 is a driver of idiopathic pulmonary fibrosis. Am J Respir Crit Care Med (2014) 190:185-95. doi:10.1164/rccm.201401-0079OC

47. Konigshoff M, Kramer M, Balsara N, Wilhelm J, Amarie OV, Jahn A, et al. WNT1-inducible signaling protein-1 mediates pulmonary fibrosis in mice and is upregulated in humans with idiopathic pulmonary fibrosis. J Clin Invest (2009) 119:772-87. doi:10.1172/JCI33950
48. Bridges RS, Kass D, Loh K, Glackin C, Borczuk AC, Greenberg S. Gene expression profiling of pulmonary fibrosis identifies Twist1 as an antiapoptotic molecular "rectifier" of growth factor signaling. Am J Pathol (2009) 175:2351-61. doi:10.2353/ajpath.2009.080954

49. Emblom-Callahan MC, Chhina MK, Shlobin OA, Ahmad S, Reese ES, Iyer EP, et al. Genomic phenotype of non-cultured pulmonary fibroblasts in idiopathic pulmonary fibrosis. Genomics (2010) 96:134-45. doi:10.1016/j. ygeno.2010.04.005

50. Tzouvelekis A, Yu G, Lino Cardenas CL, Herazo-Maya JD, Wang R, Woolard T, et al. SH2 domain-containing phosphatase-2 is a novel antifibrotic regulator in pulmonary fibrosis. Am J Respir Crit Care Med (2017) 195:500-14. doi:10.1164/rccm.201602-0329OC

51. Yang IV, Luna LG, Cotter J, Talbert J, Leach SM, Kidd R, et al. The peripheral blood transcriptome identifies the presence and extent of disease in idiopathic pulmonary fibrosis. PLoS One (2012) 7:e37708. doi:10.1371/journal. pone. 0037708

52. Englert JM, Hanford LE, Kaminski N, Tobolewski JM, Tan RJ, Fattman CL, et al. A role for the receptor for advanced glycation end products in idiopathic pulmonary fibrosis. Am J Pathol (2008) 172:583-91. doi:10.2353/ajpath. 2008.070569

53. Bueno M, Lai YC, Romero Y, Brands J, St Croix CM, Kamga C, et al. PINK1 deficiency impairs mitochondrial homeostasis and promotes lung fibrosis. J Clin Invest (2015) 125:521-38. doi:10.1172/JCI74942

54. Yu G, Tzouvelekis A, Wang R, Herazo-Maya JD, Ibarra GH, Srivastava A, et al. Thyroid hormone inhibits lung fibrosis in mice by improving epithelial mitochondrial function. Nat Med (2018) 24:39-49. doi:10.1038/ nm. 4447

55. Selman M, Ruiz V, Cabrera S, Segura L, Ramirez R, Barrios R, et al. TIMP-1, -2, -3 , and -4 in idiopathic pulmonary fibrosis. A prevailing nondegradative lung microenvironment? Am J Physiol Lung Cell Mol Physiol (2000) 279:L562-74. doi:10.1152/ajplung.2000.279.3.L562

56. Maldonado M, Salgado-Aguayo A, Herrera I, Cabrera S, Ortiz-Quintero B, Staab-Weijnitz CA, et al. Upregulation and nuclear location of MMP28 in alveolar epithelium of idiopathic pulmonary fibrosis. Am J Respir Cell Mol Biol (2018). doi:10.1165/rcmb.2017-0223OC

57. Pardo A, Selman M, Kaminski N. Approaching the degradome in idiopathic pulmonary fibrosis. Int J Biochem Cell Biol (2008) 40:1141-55. doi:10.1016/j. biocel.2007.11.020

58. Pardo A, Cabrera S, Maldonado M, Selman M. Role of matrix metalloproteinases in the pathogenesis of idiopathic pulmonary fibrosis. Respir Res (2016) 17:23. doi:10.1186/s12931-016-0343-6

59. Selman M, Pardo A. Idiopathic pulmonary fibrosis: an epithelial/fibroblastic cross-talk disorder. Respir Res (2002) 3:3. doi:10.1186/rr175

60. Selman M, Pardo A. Role of epithelial cells in idiopathic pulmonary fibrosis: from innocent targets to serial killers. Proc Am Thorac Soc (2006) 3:364-72. doi:10.1513/pats.200601-003TK

61. Yang IV, Coldren CD, Leach SM, Seibold MA, Murphy E, Lin J, et al. Expression of cilium-associated genes defines novel molecular subtypes of idiopathic pulmonary fibrosis. Thorax (2013) 68:1114-21. doi:10.1136/ thoraxjnl-2012-202943

62. Chambers RC, Leoni P, Kaminski N, Laurent GJ, Heller RA. Global expression profiling of fibroblast responses to transforming growth factor-betal reveals the induction of inhibitor of differentiation-1 and provides evidence of smooth muscle cell phenotypic switching. Am J Pathol (2003) 162:533-46. doi:10.1016/S0002-9440(10)63847-3

63. Vuga LJ, Milosevic J, Pandit K, Ben-Yehudah A, Chu Y, Richards T, et al. Cartilage oligomeric matrix protein in idiopathic pulmonary fibrosis. PLoS One (2013) 8:e83120. doi:10.1371/journal.pone.0083120

64. Chilosi M, Poletti V, Zamo A, Lestani M, Montagna L, Piccoli P, et al. Aberrant Wnt/beta-catenin pathway activation in idiopathic pulmonary fibrosis. Am J Pathol (2003) 162:1495-502. doi:10.1016/S0002-9440(10)64282-4

65. Selman M, Pardo A, Kaminski N. Idiopathic pulmonary fibrosis: aberrant recapitulation of developmental programs? PLoS Med (2008) 5:e62. doi:10.1371/ journal.pmed.0050062

66. Henderson WR Jr, Chi EY, Ye X, Nguyen C, Tien YT, Zhou B, et al. Inhibition of Wnt/beta-catenin/CREB binding protein (CBP) signaling reverses pulmonary fibrosis. Proc Natl Acad Sci U S A (2010) 107:14309-14. doi:10.1073/ pnas. 1001520107 
67. Corbett L, Mann J, Mann DA. Non-canonical wnt predominates in activated rat hepatic stellate cells, influencing HSC survival and paracrine stimulation of Kupffer cells. PLoS One (2015) 10:e0142794. doi:10.1371/journal. pone.0142794

68. Guan S, Zhou J. Frizzled-7 mediates TGF-beta-induced pulmonary fibrosis by transmitting non-canonical Wnt signaling. Exp Cell Res (2017) 359:226-34. doi:10.1016/j.yexcr.2017.07.025

69. Patel AS, Song JW, Chu SG, Mizumura K, Osorio JC, Shi Y, et al. Epithelial cell mitochondrial dysfunction and PINK1 are induced by transforming growth factor-betal in pulmonary fibrosis. PLoS One (2015) 10:e0121246. doi:10.1371/journal.pone.0121246

70. Zhao YD, Yin L, Archer S, Lu C, Zhao G, Yao Y, et al. Metabolic heterogeneity of idiopathic pulmonary fibrosis: a metabolomic study. BMJ Open Respir Res (2017) 4:e000183. doi:10.1136/bmjresp-2017-000183

71. Xie N, Tan Z, Banerjee S, Cui H, Ge J, Liu RM, et al. Glycolytic reprogramming in myofibroblast differentiation and lung fibrosis. Am J Respir Crit Care Med (2015) 192:1462-74. doi:10.1164/rccm.201504-0780OC

72. Xie N, Cui H, Ge J, Banerjee S, Guo S, Dubey S, et al. Metabolic characterization and RNA profiling reveal glycolytic dependence of profibrotic phenotype of alveolar macrophages in lung fibrosis. Am J Physiol Lung Cell Mol Physiol (2017) 313:L834-44. doi:10.1152/ajplung.00235.2017

73. Budinger GRS, Kohanski RA, Gan W, Kobor MS, Amaral LA, Armanios M, et al. The intersection of aging biology and the pathobiology of lung diseases: a joint NHLBI/NIA workshop. J Gerontol A Biol Sci Med Sci (2017) 72:1492-500. doi:10.1093/gerona/glx090

74. Mora AL, Bueno M, Rojas M. Mitochondria in the spotlight of aging and idiopathic pulmonary fibrosis. J Clin Invest (2017) 127:405-14. doi:10.1172/ JCI87440

75. Hsu E, Shi H, Jordan RM, Lyons-Weiler J, Pilewski JM, Feghali-Bostwick CA. Lung tissues in patients with systemic sclerosis have gene expression patterns unique to pulmonary fibrosis and pulmonary hypertension. Arthritis Rheum (2011) 63:783-94. doi:10.1002/art.30159

76. Rajkumar R, Konishi K, Richards TJ, Ishizawar DC, Wiechert AC, Kaminski N, et al. Genomewide RNA expression profiling in lung identifies distinct signatures in idiopathic pulmonary arterial hypertension and secondary pulmonary hypertension. Am J Physiol Heart Circ Physiol (2010) 298:H1235-48. doi:10.1152/ajpheart.00254.2009

77. Clarke LA, Botelho HM, Sousa L, Falcao AO, Amaral MD. Transcriptome meta-analysis reveals common differential and global gene expression profiles in cystic fibrosis and other respiratory disorders and identifies CFTR regulators. Genomics (2015) 106:268-77. doi:10.1016/j.ygeno.2015.07.005

78. Hoffmann J, Wilhelm J, Marsh LM, Ghanim B, Klepetko W, Kovacs G, et al. Distinct differences in gene expression patterns in pulmonary arteries of patients with chronic obstructive pulmonary disease and idiopathic pulmonary fibrosis with pulmonary hypertension. Am J Respir Crit Care Med (2014) 190:98-111. doi:10.1164/rccm.201401-0037OC

79. Patel NM, Kawut SM, Jelic S, Arcasoy SM, Lederer DJ, Borczuk AC. Pulmonary arteriole gene expression signature in idiopathic pulmonary fibrosis. Eur Respir J (2013) 41:1324-30. doi:10.1183/09031936.00084112

80. Kaminski N, Rosas IO. Gene expression profiling as a window into idiopathic pulmonary fibrosis pathogenesis: can we identify the right target genes? Proc Am Thorac Soc (2006) 3:339-44. doi:10.1513/pats.200601-011TK

81. Choi Y, Lu J, Hu Z, Pankratz DG, Jiang H, Cao M, et al. Analytical performance of Envisia: a genomic classifier for usual interstitial pneumonia. BMC Pulm Med (2017) 17:141. doi:10.1186/s12890-017-0485-4

82. Pankratz DG, Choi Y, Imtiaz U, Fedorowicz GM, Anderson JD, Colby TV, et al. Usual interstitial pneumonia can be detected in transbronchial biopsies using machine learning. Ann Am Thorac Soc (2017) 14:1646-54. doi:10.1513/ AnnalsATS.201612-947OC

83. Greene KE, King TE Jr, Kuroki Y, Bucher-Bartelson B, Hunninghake GW, Newman LS, et al. Serum surfactant proteins-A and -D as biomarkers in idiopathic pulmonary fibrosis. Eur Respir J (2002) 19:439-46. doi:10.1183/0 9031936.02.00081102

84. Kahloon RA, Xue J, Bhargava A, Csizmadia E, Otterbein L, Kass DJ, et al. Patients with idiopathic pulmonary fibrosis with antibodies to heat shock protein 70 have poor prognoses. Am J Respir Crit Care Med (2013) 187:768-75. doi:10.1164/rccm.201203-0506OC
85. Huang Y, Ma SF, Vij R, Oldham JM, Herazo-Maya J, Broderick SM, et al. A functional genomic model for predicting prognosis in idiopathic pulmonary fibrosis. BMC Pulm Med (2015) 15:147. doi:10.1186/s12890-015-0142-8

86. Herazo-Maya JD, Noth I, Duncan SR, Kim S, Ma SF, Tseng GC, et al. Peripheral blood mononuclear cell gene expression profiles predict poor outcome in idiopathic pulmonary fibrosis. Sci Transl Med (2013) 5:205ra136. doi:10.1126/scitranslmed.3005964

87. Herazo-Maya JD, Sun J, Molyneaux PL, Li Q, Villalba JA, Tzouvelekis A, et al. Validation of a 52-gene risk profile for outcome prediction in patients with idiopathic pulmonary fibrosis: an international, multicentre, cohort study. Lancet Respir Med (2017) 5:857-68. doi:10.1016/S2213-2600(17)30349-1

88. Lindell KO, Erlen JA, Kaminski N. Lessons from our patients: development of a warm autopsy program. PLoS Med (2006) 3:e234. doi:10.1371/journal. pmed.0030234

89. Mckeown S, Richter AG, O'Kane C, Mcauley DF, Thickett DR. MMP expression and abnormal lung permeability are important determinants of outcome in IPF. Eur Respir J (2009) 33:77-84. doi:10.1183/09031936.00060708

90. Hamai K, Iwamoto H, Ishikawa N, Horimasu Y, Masuda T, Miyamoto S, et al. Comparative study of circulating MMP-7, CCL18, KL-6, SP-A, and SP-D as disease markers of idiopathic pulmonary fibrosis. Dis Markers (2016) 2016:4759040. doi:10.1155/2016/4759040

91. Armstrong HF, Podolanczuk AJ, Barr RG, Oelsner EC, Kawut SM, Hoffman EA, et al. Serum matrix metalloproteinase-7, respiratory symptoms, and mortality in community-dwelling adults: the multi-ethnic study of atherosclerosis. Am J Respir Crit Care Med (2017) 196:1311-7. doi:10.1164/rccm.201701-0254OC

92. Tzouvelekis A, Herazo-Maya JD, Slade M, Chu JH, Deiuliis G, Ryu C, et al. Validation of the prognostic value of MMP-7 in idiopathic pulmonary fibrosis. Respirology (2017) 22:486-93. doi:10.1111/resp.12920

93. Vuga LJ, Tedrow JR, Pandit KV, Tan J, Kass DJ, Xue J, et al. C-X-C motif chemokine 13 (CXCL13) is a prognostic biomarker of idiopathic pulmonary fibrosis. Am J Respir Crit Care Med (2014) 189:966-74. doi:10.1164/ rccm.201309-1592OC

94. Lee JU, Cheong HS, Shim EY, Bae DJ, Chang HS, Uh ST, et al. Gene profile of fibroblasts identify relation of CCL8 with idiopathic pulmonary fibrosis. Respir Res (2017) 18:3. doi:10.1186/s12931-016-0493-6

95. Bauer Y, White ES, De Bernard S, Cornelisse P, Leconte I, Morganti A, et al. MMP-7 is a predictive biomarker of disease progression in patients with idiopathic pulmonary fibrosis. ERJ Open Res (2017) 3:00074-2016. doi:10.1183/23120541.00074-2016

96. Huang Y, Ma SF, Espindola MS, Vij R, Oldham JM, Huffnagle GB, et al. Microbes are associated with host innate immune response in idiopathic pulmonary fibrosis. Am J Respir Crit Care Med (2017) 196:208-19. doi:10.1164/ rccm.201607-1525OC

97. Mestdagh P, Vandesompele J, Brusselle G, Vermaelen K. Non-coding RNAs and respiratory disease. Thorax (2015) 70:388-90. doi:10.1136/ thoraxjnl-2014-206404

98. Pandit KV, Corcoran D, Yousef H, Yarlagadda M, Tzouvelekis A, Gibson KF, et al. Inhibition and role of let-7d in idiopathic pulmonary fibrosis. $A m$ J Respir Crit Care Med (2010) 182:220-9. doi:10.1164/rccm.200911-1698OC

99. Milosevic J, Pandit K, Magister M, Rabinovich E, Ellwanger DC, Yu G, et al. Profibrotic role of miR-154 in pulmonary fibrosis. Am J Respir Cell Mol Biol (2012) 47:879-87. doi:10.1165/rcmb.2011-0377OC

100. Schulz MH, Pandit KV, Lino Cardenas CL, Ambalavanan N, Kaminski N, Bar-Joseph Z. Reconstructing dynamic microRNA-regulated interaction networks. Proc Natl Acad Sci U S A (2013) 110:15686-91. doi:10.1073/pnas. 1303236110

101. Mizuno K, Mataki H, Seki N, Kumamoto T, Kamikawaji K, Inoue H. MicroRNAs in non-small cell lung cancer and idiopathic pulmonary fibrosis. J Hum Genet (2017) 62:57-65. doi:10.1038/jhg.2016.98

102. Nho RS. Alteration of aging-dependent microRNAs in idiopathic pulmonary fibrosis. Drug Dev Res (2015) 76:343-53. doi:10.1002/ddr.21272

103. Selman M, Lopez-Otin C, Pardo A. Age-driven developmental drift in the pathogenesis of idiopathic pulmonary fibrosis. Eur Respir J (2016) 48:538-52. doi:10.1183/13993003.00398-2016

104. Liu G, Friggeri A, Yang Y, Milosevic J, Ding Q, Thannickal VJ, et al. miR-21 mediates fibrogenic activation of pulmonary fibroblasts and lung fibrosis. J Exp Med (2010) 207:1589-97. doi:10.1084/jem.20100035 
105. Pandit KV, Milosevic J. MicroRNA regulatory networks in idiopathic pulmonary fibrosis. Biochem Cell Biol (2015) 93:129-37. doi:10.1139/bcb-2014-0101

106. Deng Z, He Y, Yang X, Shi H, Shi A, Lu L, et al. MicroRNA-29: a crucial player in fibrotic disease. Mol Diagn Ther (2017) 21:285-94. doi:10.1007/ s40291-016-0253-9

107. Van Rooij E, Sutherland LB, Thatcher JE, Dimaio JM, Naseem RH, Marshall WS, et al. Dysregulation of microRNAs after myocardial infarction reveals a role of miR-29 in cardiac fibrosis. Proc Natl Acad Sci U S A (2008) 105:13027-32. doi:10.1073/pnas.0805038105

108. Maurer B, Stanczyk J, Jungel A, Akhmetshina A, Trenkmann M, Brock M, et al. MicroRNA-29, a key regulator of collagen expression in systemic sclerosis. Arthritis Rheum (2010) 62:1733-43. doi:10.1002/art.27443

109. Qin W, Chung AC, Huang XR, Meng XM, Hui DS, Yu CM, et al. TGF-beta/ Smad3 signaling promotes renal fibrosis by inhibiting miR-29. J Am Soc Nephrol (2011) 22:1462-74. doi:10.1681/ASN.2010121308

110. Roderburg C, Urban GW, Bettermann K, Vucur M, Zimmermann H, Schmidt S, et al. Micro-RNA profiling reveals a role for miR-29 in human and murine liver fibrosis. Hepatology (2011) 53:209-18. doi:10.1002/hep.23922

111. Wang B, Komers R, Carew R, Winbanks CE, Xu B, Herman-Edelstein M, et al. Suppression of microRNA-29 expression by TGF-betal promotes collagen expression and renal fibrosis. J Am Soc Nephrol (2012) 23:252-65. doi:10.1681/ASN.2011010055

112. Nijhuis A, Biancheri P, Lewis A, Bishop CL, Giuffrida P, Chan C, et al. In Crohn's disease fibrosis-reduced expression of the miR-29 family enhances collagen expression in intestinal fibroblasts. Clin Sci (Lond) (2014) 127:341-50. doi:10.1042/CS20140048

113. Zhang GY, Wu LC, Liao T, Chen GC, Chen YH, Zhao YX, et al. A novel regulatory function for miR-29a in keloid fibrogenesis. Clin Exp Dermatol (2016) 41:341-5. doi:10.1111/ced.12734

114. Pandit KV, Milosevic J, Kaminski N. MicroRNAs in idiopathic pulmonary fibrosis. Transl Res (2011) 157:191-9. doi:10.1016/j.trsl.2011.01.012

115. Cushing L, Kuang PP, Qian J, Shao F, Wu J, Little F, et al. miR-29 is a major regulator of genes associated with pulmonary fibrosis. Am J Respir Cell Mol Biol (2011) 45:287-94. doi:10.1165/rcmb.2010-0323OC

116. Parker MW, Rossi D, Peterson M, Smith K, Sikstrom K, White ES, et al. Fibrotic extracellular matrix activates a profibrotic positive feedback loop. J Clin Invest (2014) 124:1622-35. doi:10.1172/JCI71386

117. Xiao J, Meng XM, Huang XR, Chung AC, Feng YL, Hui DS, et al. miR-29 inhibits bleomycin-induced pulmonary fibrosis in mice. Mol Ther (2012) 20:1251-60. doi:10.1038/mt.2012.36

118. Montgomery RL, Yu G, Latimer PA, Stack C, Robinson K, Dalby CM, et al. MicroRNA mimicry blocks pulmonary fibrosis. EMBO Mol Med (2014) 6:1347-56. doi:10.15252/emmm.201303604

119. Xie T, Liang J, Geng Y, Liu N, Kurkciyan A, Kulur V, et al. MicroRNA-29c prevents pulmonary fibrosis by regulating epithelial cell renewal and apoptosis. Am J Respir Cell Mol Biol (2017) 57:721-32. doi:10.1165/rcmb.2017-0133OC

120. Durrani-Kolarik S, Pool CA, Gray A, Heyob KM, Cismowski MJ, Pryhuber G, et al. miR-29b supplementation decreases expression of matrix proteins and improves alveolarization in mice exposed to maternal inflammation and neonatal hyperoxia. Am J Physiol Lung Cell Mol Physiol (2017) 313:L339-49. doi:10.1152/ajplung.00273.2016

121. Katzenstein AL, Myers JL. Idiopathic pulmonary fibrosis: clinical relevance of pathologic classification. Am J Respir Crit Care Med (1998) 157:1301-15. doi:10.1164/ajrccm.157.4.9707039

122. Visscher DW, Myers JL. Histologic spectrum of idiopathic interstitial pneumonias. Proc Am Thorac Soc (2006) 3:322-9. doi:10.1513/pats.200602-019TK

123. Depianto DJ, Chandriani S, Abbas AR, Jia G, N'Diaye EN, Caplazi P, et al. Heterogeneous gene expression signatures correspond to distinct lung pathologies and biomarkers of disease severity in idiopathic pulmonary fibrosis. Thorax (2015) 70:48-56. doi:10.1136/thoraxjnl-2013-204596

124. Xu Y, Mizuno T, Sridharan A, Du Y, Guo M, Tang J, et al. Single-cell RNA sequencing identifies diverse roles of epithelial cells in idiopathic pulmonary fibrosis. JCI Insight (2016) 1:e90558. doi:10.1172/jci.insight.90558

125. Misharin AV, Morales-Nebreda L, Reyfman PA, Cuda CM, Walter JM, Mcquattie-Pimentel AC, et al. Monocyte-derived alveolar macrophages drive lung fibrosis and persist in the lung over the life span. J Exp Med (2017) 214:2387-404. doi:10.1084/jem.20162152

126. White ES, Brown KK, Collard HR, Conoscenti CS, Cosgrove GP, Flaherty KR, et al. Open-access biorepository for idiopathic pulmonary fibrosis. The way forward. Ann Am Thorac Soc (2014) 11:1171-5. doi:10.1513/AnnalsATS. 201406-289OI

127. Ardini-Poleske ME, Clark RF, Ansong C, Carson JP, Corley RA, Deutsch GH, et al. LungMAP: the molecular atlas of lung development program. Am J Physiol Lung Cell Mol Physiol (2017) 313(5):L733-40. doi:10.1152/ajplung. 00139.02017

128. Du Y, Kitzmiller JA, Sridharan A, Perl AK, Bridges JP, Misra RS, et al. Lung gene expression analysis (LGEA): an integrative web portal for comprehensive gene expression data analysis in lung development. Thorax (2017) 72:481-4. doi:10.1136/thoraxjnl-2016-209598

129. Ding J, Aronow B, Kaminski N, Kitzmiller J, Whitsett J, Bar-Joseph Z Reconstructing differentiation networks and their regulation from time series single cell expression data. Genome Res (2018) 28:383-95. doi:10.1101/ gr.225979.117

Conflict of Interest Statement: NK is an inventor on a pending patent on use of thyroid hormone as an antifibrotic agent (licensed), as well as a patent on novel biomarkers in IPF (not licensed). NK consulted Biogen Idec, Boehringer Ingelheim, Numedii, MMI, Pliant, Third Rock, and Samumed. NK has an ongoing collaboration with MiRagen but no fund exchange. The other author declares that the research was conducted in the absence of any commercial or financial relationships that could be construed as a potential conflict of interest.

Copyright (C) 2018 Vukmirovic and Kaminski. This is an open-access article distributed under the terms of the Creative Commons Attribution License (CC BY). The use, distribution or reproduction in other forums is permitted, provided the original author(s) and the copyright owner are credited and that the original publication in this journal is cited, in accordance with accepted academic practice. No use, distribution or reproduction is permitted which does not comply with these terms. 